\title{
Design and development of an irrigation mobile robot
}

\author{
Ahmed Hassan', Rao M. Asif ${ }^{2}$, Ateeq Ur Rehman ${ }^{3}$, Zuhaib Nishtar ${ }^{4}$, Mohammed K. A. Kaabar, \\ Khan Afsar 6 \\ ${ }^{1,2,4}$ Department of Electrical Engineering, The Superior College, Lahore, Pakistan \\ ${ }^{3}$ Department of Electrical Engineering, Government College University, Lahore, Pakistan \\ ${ }^{3}$ College of Internet of Things Engineering, Hohai University, Changzhou Campus, Changzhou, China \\ ${ }^{5}$ Department of Mathematics and Statistics, Washington State University, Pullman, United States \\ ${ }^{6}$ Electrical and Computer Engineering Department, COMSATS University Islamabad, Pakistan
}

\begin{tabular}{|c|c|}
\hline Article Info & ABSTRACT \\
\hline & \multirow{9}{*}{$\begin{array}{l}\text { Water plays a significant role among other existing natural resources. The } \\
\text { daily demand for water supplies is increasingly on the rise as the population } \\
\text { grows. To minimize the consumption of water in irrigation, several proposals } \\
\text { were suggested. The currently existing system known as the automated } \\
\text { irrigation system for effective water resource use with the prediction of the } \\
\text { weather (AISWP) functions with a single farm that lacks the reliability in the } \\
\text { precision of weather forecasting. So, a robot-based irrigation system has been } \\
\text { proposed to improve the performance of the system. To minimize the water } \\
\text { usage for crops, an automated irrigation system has been developed which } \\
\text { irrigates the field in acres. An additional characteristic of the system has also } \\
\text { been given for the soil pH measurement to allow the use of fertilizers } \\
\text { accordingly. The solar-powered robot is managed wirelessly by a designated } \\
\text { application. The robot is attached with various sensors and with a high- } \\
\text { resolution camera that tests crop conditions and senses the soil state. The } \\
\text { application has been created to provide information about the soil's condition } \\
\text { such as temperature level, humidity level, water level, and level of nutrients } \\
\text { to the PC/Laptop with the real-time values via the GSM module. }\end{array}$} \\
\hline Received Dec 14, 2020 & \\
\hline Revised Feb 9, 2021 & \\
\hline Accepted Apr 9, 2021 & \\
\hline Keywords: & \\
\hline GSM & \\
\hline IoT & \\
\hline Smart irrigation & \\
\hline & \\
\hline
\end{tabular}

This is an open access article under the CC BY-SA license.

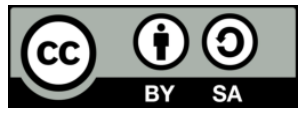

Corresponding Author:

Ateeq Ur Rehman

Department of Electrical Engineering

Government College University

Science Block, Katcheri Road, Lower Mall, Lahore, Pakistan

Email: ateeq.rehman@gcu.edu.pk

\section{INTRODUCTION}

Irrigation is the mechanism by which plants are supplied with water by artificial means. Irrigation decreases the production of weeds and increases the growth of plants to conserve soil nutrients. Irrigation can support landscape conservation in growing crops, especially in periods of below average precipitation [1]. Water is slowly absorbed by plant roots; therefore, water consumption is minimized. Irrigation enables farmers and gardeners to use water effectively to ensure the growth of plants. The farmers of stocks use irrigation to ensure that their cattle can produce enough milk. Many new crops and varieties of plants need daily irrigation which leads to the increased irrigated demand. An autonomous irrigation machine runs a device without human intervention. With the assistance of electronic devices and detectors, such as processors, temporaries, sensors, and other mechanical equipment, any irrigation system such as drip, sprinkler, and the surface become automated [2,3]. Besides minimizing the costs of water bills and ensuring the safety of farms, the required automatic irrigation system will also help maximize the value of our farm 
and save time. Today, the majority of new farmers foresee a greenhouse with plants such as the integrated irrigation system. Therefore, there is no need to spend from 2 to 5 hours a week cleaning the field.

As an important technology for the planting and development of crops, agricultural irrigation is often given importance. A sound and adequate supply of irrigation water can dramatically increase the efficiency of agriculture and water savings. It is clear that conventional irrigation not only absorbs wastewater but also resources, based on the local position, maybe much needed. The conventional irrigation technique entails using water in all areas of the field as evenly as possible without taking into consideration the complexity of soil and crop water needs [4]. Different closed-loop irrigation systems have been developed and applied in recent decades as they are responsive to real-time soil humidity factors. Agriculture is using $85 \%$ of worldwide available freshwater supplies, and because of the rising population and the increasing food demand, this figure might continue to dominate for water use. Water wastage is always a major concern of our society in daily life. Water availability varies drastically from region to region. Some regions have plenty of water available and some face scarcity of water. Managing water resources for agriculture is of extreme importance. Water wastage is to be minimized on an urgent basis as water consumption is increasing with the population growth rate. To overcome these losses, a robotics-based irrigation system has been designed in which the maximum field is irrigated. The field is distributed into different areas. The robot is gone through all these areas sequentially and senses the condition of the soil, which further communicates the message along with the global system for mobile communications (GSM) module through an application or mobile phone.

In [5], the authors reviewed the latest smart solar irrigation system in depth. The solar sustainable energy from solar panels to the groundwater tank is dependent on direct sunlight amount from the well to the purified water. While conventional methods involved pumping water from the pot to the pot through the pump, only a single phase of energy was absorbed by the device as the water was pumped into a ground-level tank that controls the water flow from a basic valve mechanism into the field $[6,7]$. This saved an enormous amount of power generation and renewable energies. In order to monitor moisture content and height in the soil, they developed a network of wireless sensors. The design of the wireless sensor network was seen and the results of the sensor configuration and irrigation decisions were discussed in agriculture. In addition, they have created a sophisticated wireless irrigation system with real-life humidity information and expert data for precise farming and irrigation decisions. This system has been shown to save water and be feasible for precision farming [8-12]. With this solution, the authors recommended an improved automated irrigation method [13-15]. A sprinkler head was fitted to a water supply under load by a conduit with a valve. A moisture sensor was installed on the field next to the sprinkler head. The wires between the samples and the valves were changed for the wireless version. Additional valves were used for monitoring and installation of located areas in branch and riser pipes. The rechargeable battery solar powered by the preferred fuel was supplied.

Various other studies have demonstrated multiple designs to increase the intelligent irrigation system, but the main objective of the proposed project is to create an intelligent robot to capture the crop situation with a high-resolution camera for irrigation. Researchers have provided a wireless sensor network measuring temperature and humidity parameters related to the soil [16-18]. Under soil, sensors attached to relay nodes were designed using an advanced protocol to have an extremely short operating time to increase the life cycle of the soil monitoring device. During transmission, the system was developed with the use of a microcontroller, a universal asynchronous transmitter and sensors and was sampled every hour with the data buffering (UART). Because of their cost and the positioning of the sensor in the ground the system was unpleasant to reduce the RF signal. The authors suggested a photovoltaic panel system during this point, with a duplex communication channel that can be planned using a website for data management and irrigation using a portable internet interface [19-21].

In this way, Kim [22] proposed the remote sensing and control irrigation system using a mobile network of wireless contact sensors for variable irrigation rates, in-house real-time monitoring, and linear movement irrigation system control for precise information accuracy for maximum water usage. The machine supplied with in-depth information on the device and parameters of irrigation, the wireless network of sensors, and the field sensing and tracking for the applications concerned. The whole system was based on five sensor systems in the field which are capturing the data and transmitting it to the Base Station via the GPS. Rehman et al. [23] have thus suggested a basic cost-effective smart irrigation system. The device was implemented with wireless sensor motes from a network of wireless sensors. The machine was equipped with IRIS TINY OS motors to calculate the moisture level and set the threshold value in outdoor conditions. The moisture content was calculated. The plan used the Crossbow technology-developed MOTEVIEW 2.0f data visualization and surveillance platform. Compared to other manual operators, the planned scheme was simple to enforce and demanded less of the IRIS sensor motes. The project's authors suggested the implementation of a drip irrigation device based on the microcontroller. This device was a feedback control device in real-

IAES Int J Rob \& Autom, Vol. 10, No. 2, June 2021 : 75 - 90 
time that could track and control all the processes in a drip irrigation system very effectively. They also built an irrigation system that manages valves using an automatic controller, which enables farmers to use the necessary water's volume at the right time [24].

The authors suggested an integrated irrigation system that automatically waters and retains the necessary soil moisture content. The Arduino UNO framework was used for the development of the control unit with the ATMEGA328P microcontroller. The installation utilizes soil humidity sensors that determine the exact humidity level in the soil. This importance allowed the machine to use a suitable amount of water that prevents irrigation. IoT was used to brief farmers on sprinkler's status. The sensor details have been frequently updated on the GSM-GPRS SIM900A modem to ensure that the water sprinklers are ON/OFF at all times. The sensors are available on the website. The sensor readings have also been sent to a Thing Speech channel for study [25]. The work was carried out using the soil system using sensors based on this process [26]. Different soil sensors have been used to measure the values of temperature, humidity, and sun, moisture, and $\mathrm{pH}$. The soil sensing information was then transmitted from the A/D converter to the cloud via Raspberry Pi to the MCP3204 A/D converter. The details were stored in the cloud on both cell and laptop computers. They understood that based on the knowledge, the increasing crop is acceptable for the parameter of the soil. This state-of-the-art equipment also makes land monitoring processes simple for farmers to remember the specific soil quality. All the projects carried out up to date consist primarily of IoT irrigation systems. In this phase [27], the authors have established an effective, inexpensive, and ready low-level discharge calculation to implement the vast water system in the GSM/GPRS irrigation channel network of the river basin of the Indus River as a suitable communication technology. Problems relating to power needs, and device operation have been discussed and resolved.

The authors suggested this approach, using soil humidity sensors, to prevent wastewater and improve irrigation productivity using a PLC-based irrigation system [28]. It is also upgraded the conventional irrigation method, which allows for high quality and low water utilization of the irrigation system. The best attribute was that of a PLC-based sprinkler irrigation scheme. In this approach, the authors suggested a cloudbased IoT agricultural greenhouse monitoring system. In greenhouses, sensors including light sensors, and others such as temperature, humidity, etc. for many environmental parameters have been efficiently regulated for the management. Periodically (30 seconds), sensors collected and stored data from the agricultural sector through cloud storage and the internet [29, 30]. The authors have talked about IoT-based crop surveillance and irrigation system [31]. A system was designed to track farmland with sensors and the method of irrigation was automated based on sensed data according to a decision of a server. The corresponding outcomes are transmitted via wireless technology to the Web server database. This automated irrigation guarantees that the humidity and temperature areas are below the maximum limit. The user can remotely monitor and manage the system using an application that provides a web interface to users. The researchers suggested an intelligent scheme of irrigation with this process. This proposed device used an Android mobile application to decrease human interference and to remotely monitor the crop field. With the drip irrigation system, we can save a lot of wastewater. A few more devices have been used to track the environment [32]. The advantages and disadvantages of existing irrigation models are summarized in Table 1.

Table 1. Pros and cons of various existing irrigation models

\begin{tabular}{|c|c|c|c|}
\hline Ref & Model Designed & Advantages & Disadvantages \\
\hline [1-3] & $\begin{array}{l}\text { A cellular use of automation of soil moisture sensors for drip } \\
\text { irrigation }\end{array}$ & Self-healing & Slow irrigation process \\
\hline [4-8] & Remotely sensed data of a centralized WSN irrigation system & Flexible and easy to expand & $\begin{array}{l}\text { Cannot irrigate the } \\
\text { maximum area }\end{array}$ \\
\hline$[9-13]$ & A novel soil measuring wireless sensor network & $\begin{array}{l}\text { Greater precision in } \\
\text { maintaining soil moisture }\end{array}$ & Requiring labor \\
\hline [14-19] & A review of wireless sensor and wireless network technologies & Reduced erosion & Periodic service is required \\
\hline [20-22] & A design of a wireless sensor network for greenhouse analysis & Increased security & $\begin{array}{l}\text { The initial and long-term } \\
\text { costs are high }\end{array}$ \\
\hline [23-25] & Solar powered irrigation for food crop production & Costs have fallen & High initial cost \\
\hline [26-27] & $\begin{array}{l}\text { Verification for smart devices with a lightweight anonymous } \\
\text { source }\end{array}$ & Easy Installation & Slow response \\
\hline
\end{tabular}

The authors recommended that the automated weed detection and intelligent herbicide sprayer robot should be designed and built to detect the decrease in crops. In which photos of a plant have been obtained, the weeds of a field can accurately be recognized [33, 34]. In the method [35], the authors suggested a framework to recognize rats, crop decreases, and to submit information and image processing for up-to-date notification analysis. Sensors and electronic systems have been designed using Python scripts. Based on checked cases, $84.8 \%$ of the test cases were 
successful. An experiment with IoT and image recognition has been conducted to determine biological factors or human-produced, Smart Agriculture presented a strategy that merged IoT and image analysis that directly inhibited plant growth. The decision-making method was used to further evaluate the process of gathering information from the complicated environment structure, and the image of the lattice was performed using histogram analysis by MATLAB software [36, 37]. In this approach, the authors suggested a scheme that took into account Indian climate conditions specifications for a sugarcane crop [38]. New knowledge retrieval and processing technologies for sugarcane were developed at WSN in agriculture. It was better than conventional agricultural methods. The precise farm monitoring system was designed to capture sensor node data with wireless sensor nodes and ground stations. This was a low-cost device in which the stored information was sent through an SMS via a GSM network to a remote site. To monitor the parameters, the farmer will use the obtained information. The efficacy and reliability of used resources have been enhanced by this method of wireless sensing and control that results in better performance. The system's downside was its GSM network dependence. A detailed review of various irrigation models exploiting different model designs and wireless technologies has been demonstrated in Table 2.

Table 2. State of the art of existing irrigation models

\begin{tabular}{|c|c|c|c|}
\hline Ref & Model Designed & Advantages & Disadvantages \\
\hline$[1]$ & $\begin{array}{l}\text { A cellular use of automation of soil moisture sensors for drip } \\
\text { irrigation }\end{array}$ & Self-healing & Slow irrigation process \\
\hline$[2]$ & Remotely sensed data of a centralized WSN irrigation system & Flexible and easy to expand & $\begin{array}{l}\text { Cannot irrigate maximum } \\
\text { area }\end{array}$ \\
\hline [3] & a novel soil measuring wireless sensor network & $\begin{array}{l}\text { Greater precision in } \\
\text { maintaining soil moisture }\end{array}$ & Requiring labor \\
\hline [4] & A review of wireless sensor and wireless network technologies & Reduced erosion & Require periodic service \\
\hline [5] & A design of wireless sensor network for greenhouse analysis & Increased security & $\begin{array}{l}\text { The initial and long-term } \\
\text { costs are much higher }\end{array}$ \\
\hline$[6]$ & $\begin{array}{l}\text { A field modular gate system smart sensor based farm } \\
\text { monitoring system }\end{array}$ & Dedicated bandwidth & $\begin{array}{l}\text { Lack of mobility and greater } \\
\text { cost }\end{array}$ \\
\hline [7] & $\begin{array}{l}\text { Precision agricultural device architecture and implementation } \\
\text { using a wireless communication }\end{array}$ & Self-healing & $\begin{array}{l}\text { It lacked the cloud-based } \\
\text { data storage }\end{array}$ \\
\hline$[8]$ & $\begin{array}{l}\text { Automatic monitor and control system of water saving } \\
\text { irrigation }\end{array}$ & Product higher crop yields & Time consuming \\
\hline [9] & Automated IoT irrigation system dependent on the sensor & Smartly controlled & Data rate is low \\
\hline [10] & Automated agriculture system based on WSN & $\begin{array}{l}\text { Capable of detecting the } \\
\text { moisture level }\end{array}$ & $\begin{array}{l}\text { Lack of accuracy in sandy } \\
\text { soils }\end{array}$ \\
\hline [11] & A smart sensor array for executing irrigation in real time & Wirelessly controlled & Waste-full runoff \\
\hline [12] & $\begin{array}{l}\text { Field test remote sensing of infrared thermography for the } \\
\text { assessment of crop water }\end{array}$ & $\begin{array}{l}\text { No destructive sampling of } \\
\text { the crop }\end{array}$ & Expensive for small areas \\
\hline [13] & Cyber interactive networks lightweight safety compliance & $\begin{array}{l}\text { Not limited to specific IoT } \\
\text { services }\end{array}$ & Stable water supply need \\
\hline [14] & $\begin{array}{l}\text { Advanced and modern agricultural real-time automation and } \\
\text { control system }\end{array}$ & Ability to save water & $\begin{array}{l}\text { Rural areas cannot fulfill that } \\
\text { requirements }\end{array}$ \\
\hline [15] & $\begin{array}{l}\text { Wireless vehicle speed with crop tracking and routing system } \\
\text { sensor network }\end{array}$ & $\begin{array}{l}\text { Ideal for first-time } \\
\text { configuration }\end{array}$ & Limited to short distance \\
\hline [16] & $\begin{array}{l}\text { Green Roofs' intelligent irrigation scheme focused on expected } \\
\text { transition }\end{array}$ & Wirelessly controlled & Waste-full runoff \\
\hline [17] & A greenhouse technology integrated network/wireless system & Enhanced speed & $\begin{array}{l}\text { Installation and replacement } \\
\text { costs }\end{array}$ \\
\hline [18] & $\begin{array}{l}\text { An intelligent farmland measurement sensor driven by } \\
\text { microbial fuel cells }\end{array}$ & $\begin{array}{l}\text { It helps in the reduction of } \\
\text { pollution }\end{array}$ & $\begin{array}{l}\text { Consumption of oxygen by } \\
\text { the bacteria }\end{array}$ \\
\hline [19] & A smart and regulated agricultural climate & Flexible easy to expand & Slow response \\
\hline [20] & $\begin{array}{l}\text { Wireless networks and GPRS module automatic irrigation } \\
\text { system }\end{array}$ & $\begin{array}{l}\text { Preserves soil structure and } \\
\text { nutrients }\end{array}$ & Runoff due to overwatering \\
\hline [21] & $\begin{array}{l}\text { Smart water performance: assessment and quantitative } \\
\text { analysis of water management potential in desert areas }\end{array}$ & $\begin{array}{l}\text { AI offers the potential for } \\
\text { machine learning }\end{array}$ & $\begin{array}{l}\text { AI can be used for } \\
\text { destructive purpose by } \\
\text { destructive people }\end{array}$ \\
\hline [22] & $\begin{array}{l}\text { Creation and deployment of a distributed IoT framework to } \\
\text { track freshwater water quality }\end{array}$ & Enhanced speed & $\begin{array}{l}\text { Not suitable as a receiver, on } \\
\text { battery-based applications }\end{array}$ \\
\hline [23] & $\begin{array}{l}\text { In-situ wireless sensor network in Southern Finland for river } \\
\text { basin tracking and farming }\end{array}$ & Lack of interference & Requiring periodic service \\
\hline [24] & $\begin{array}{l}\text { Discrimination against marijuana and crops by visual } \\
\text { processing and artificial intelligence }\end{array}$ & Self-made decisions & Complex to understand \\
\hline [25] & $\begin{array}{l}\text { Develop smart agriculture, cameras, cloud infrastructure, } \\
\text { mobile devices \& big data processing }\end{array}$ & $\begin{array}{l}\text { Avoids overuse of water in } \\
\text { irrigation }\end{array}$ & Initial cost is high \\
\hline [26] & Solar powered irrigation for food crop production & Costs have fallen & High initial cost \\
\hline [27] & $\begin{array}{l}\text { Verification for smart devices with a lightweight anonymous } \\
\text { source }\end{array}$ & Easy installation & Slow response \\
\hline
\end{tabular}




\section{RESEARCH METHOD}

Firstly, the system is proposed in Proteus simulation. The functions of this system are:

- to measure the amount of NPK,

- to measure the percentage of humidity \& moisture,

- to measure the temperature, and

- the circuit diagram of the system is shown in Figure 1.

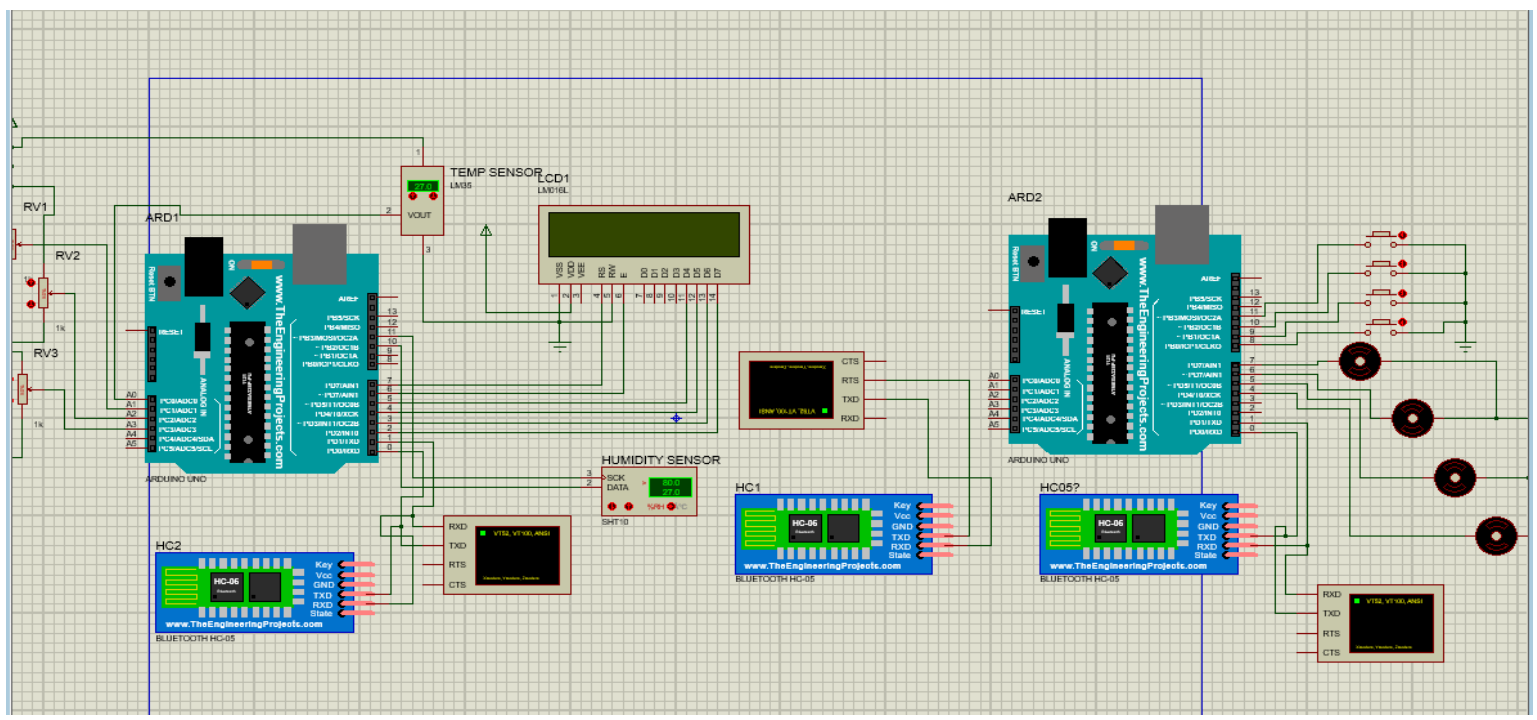

Figure 1. Circuit diagram of the proposed model

\subsection{Case 1}

In Case 1, we have given the condition of the dry soil and we get the suitable results accordingly on the software. The soil nutrients are monitored, and the other information is shown on the virtual terminal. The result of Case 1 of the system is also shown in Figure 2.

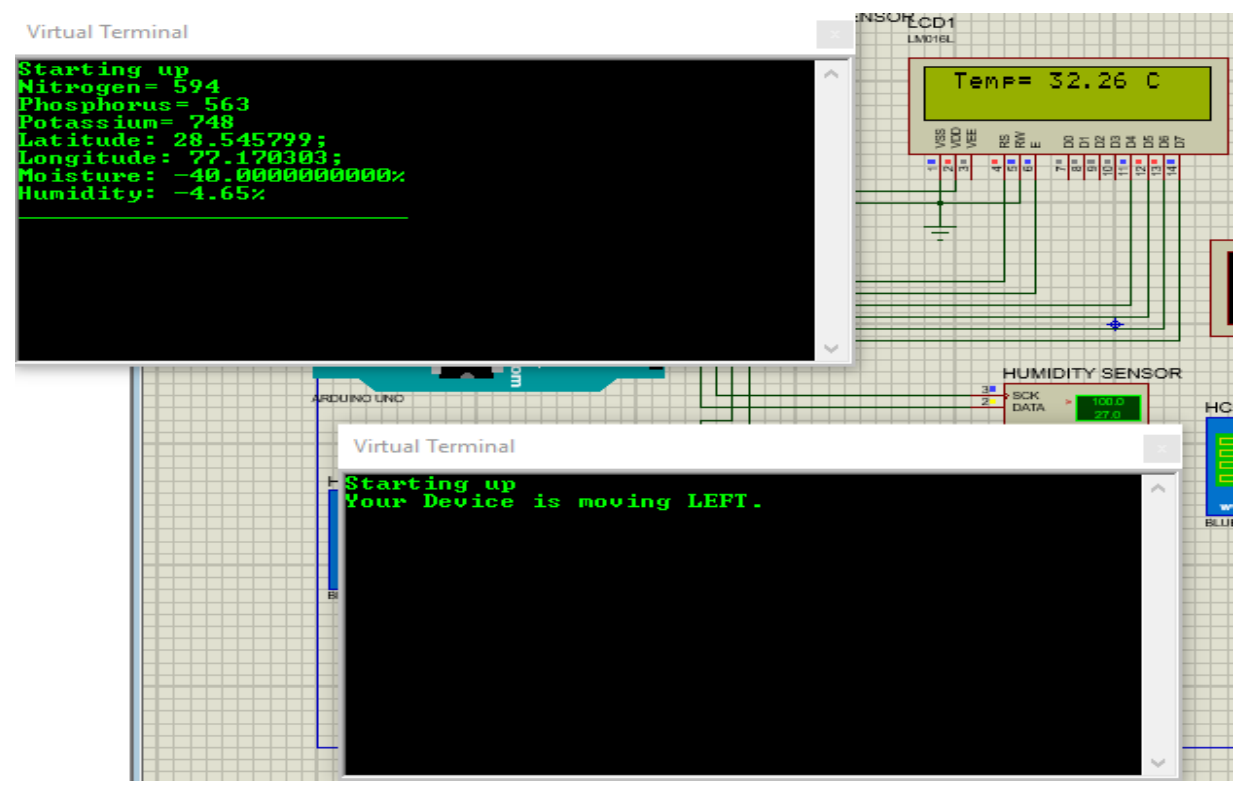

Figure 2. Results of Case 1 


\subsection{Case 2}

In Case 2, we have given the condition of the moist soil and we get the suitable results accordingly to the software. The soil nutrients are monitored, and the other information is shown on the virtual terminal. The result of Case 2 of the system is also shown in Figure 3.

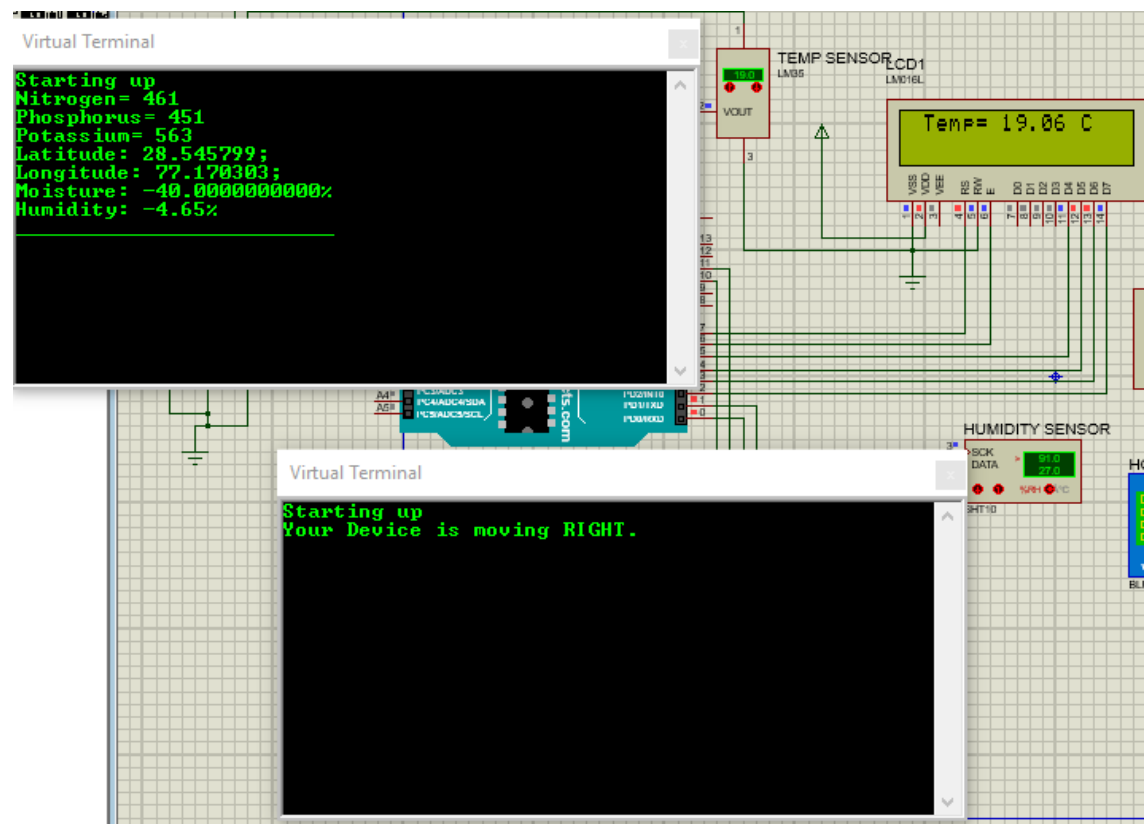

Figure 3. Results of Case 2

\subsection{Case 3}

In Case 3, we have given the condition of the wet soil and we get the suitable results accordingly on the software. The soil nutrients are monitored, and the other information is shown on the virtual terminal. The result of Case 3 of the system is also shown in Figure 4.

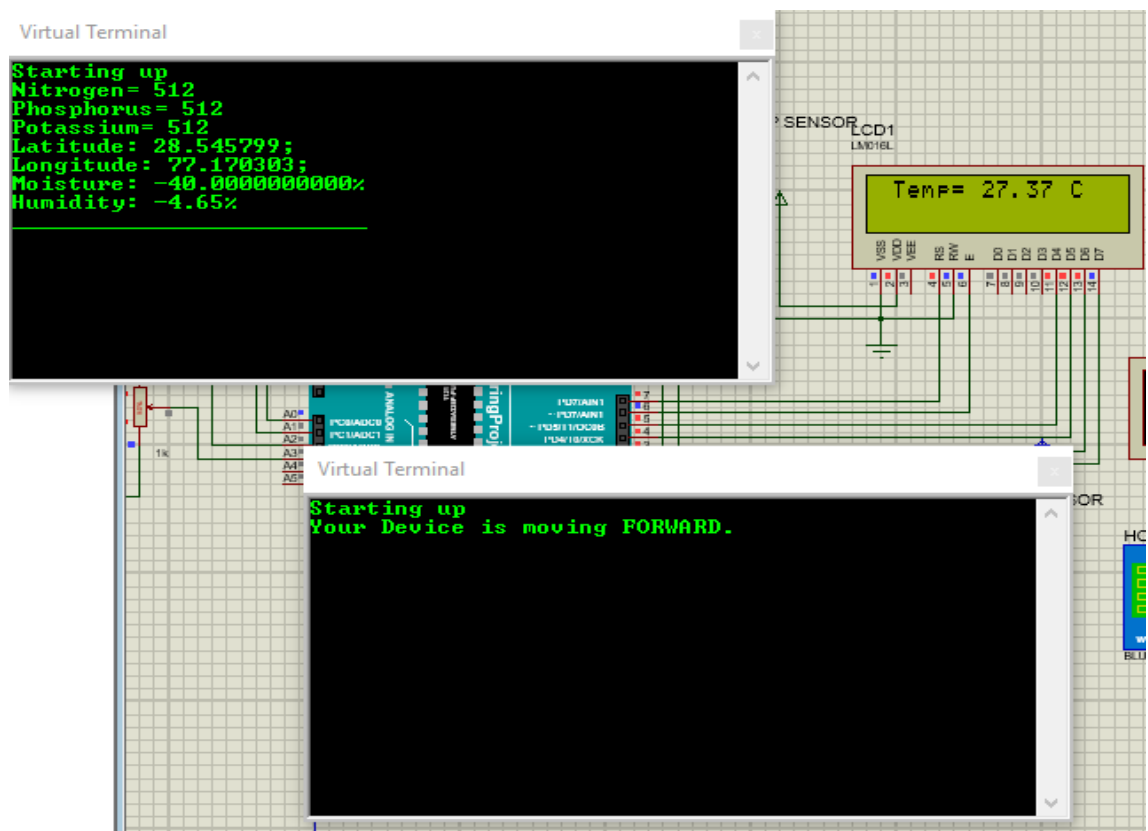

Figure 4. Results of Case 3 


\subsection{Flowcharts of remote and robot}

According to Figures 5 and 6, the motors and sensors are attached to the required pins. The Arduino board reads each signal to check if it is one of the rules defined by the user. The motors will start when the signal is applied from the designated application. The robot will move in the direction given by the application. The HC-05 Bluetooth module is used for the communication between the remote and the DC motors. The servo motor is used to dip the soil sensors. The sensors are attached to the arm of the servo motor. If the servo motor gets the pulse, it operates, and the sensors are dipped in the soil. If the sensors are dipped in the soil, then the reading will be shown on the LCD. The Bluetooth module is used to communicate the data between the mobile application and sensors and show the data on the PC/Laptop.

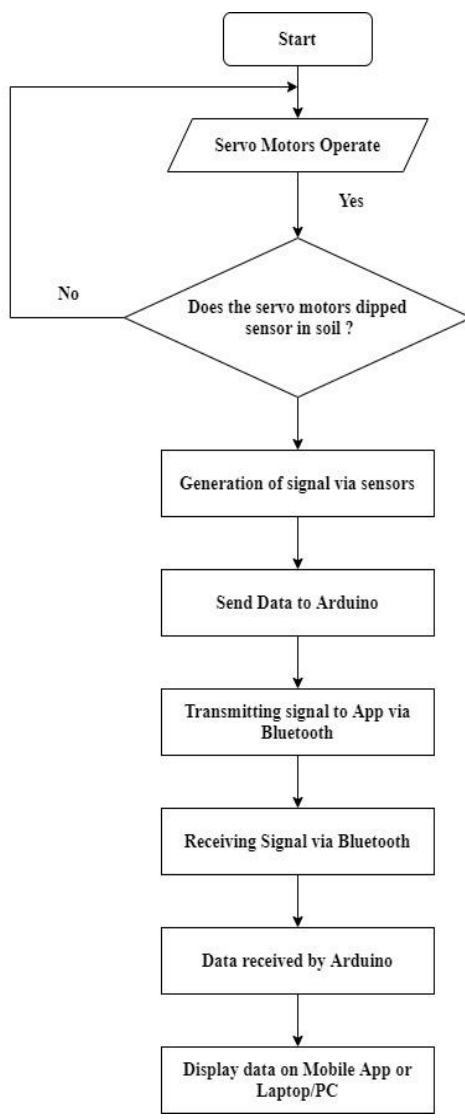

Figure 5. Flowchart of the remote deployed in the proposed model

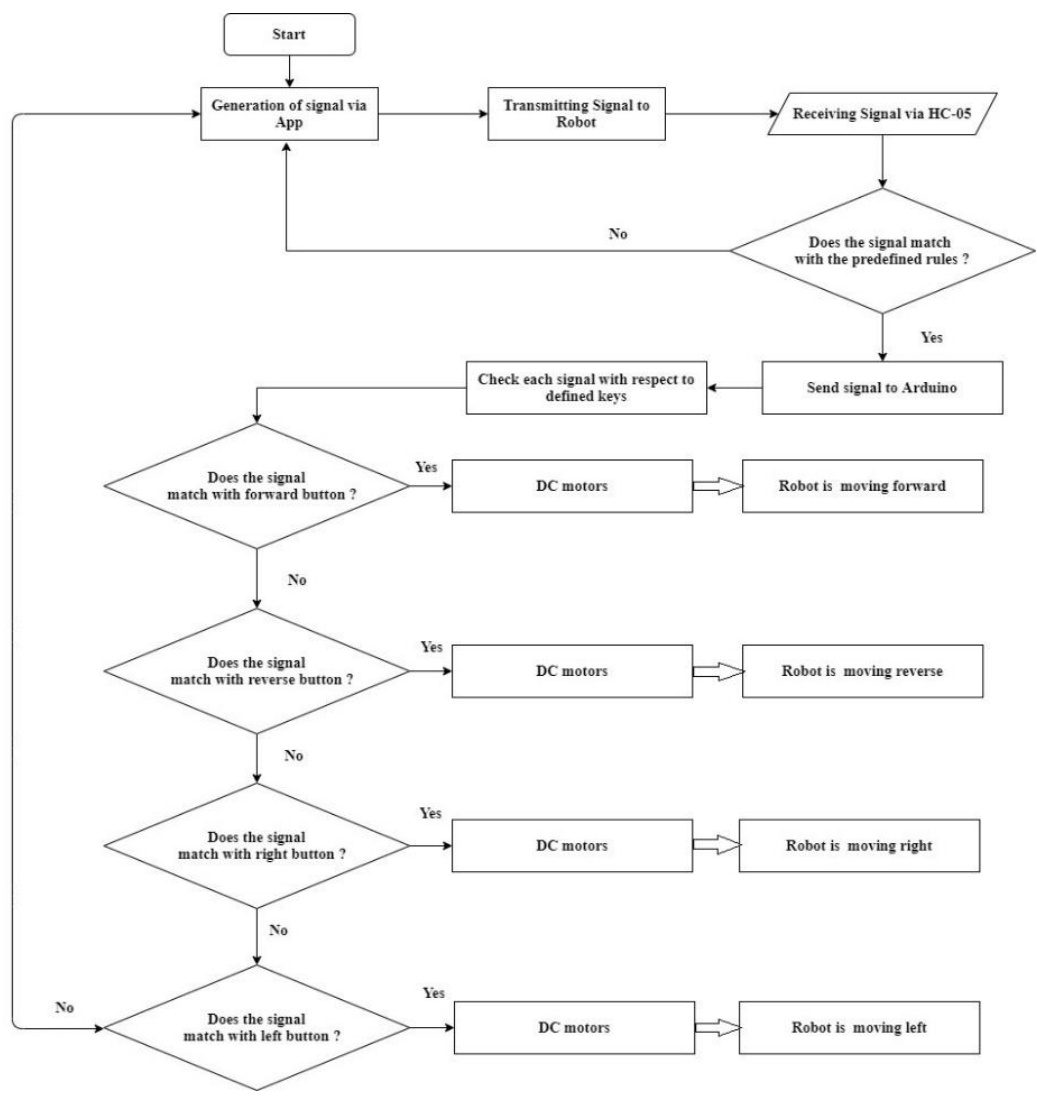

Figure 6. Demonstration of the robot's flowchart

\section{RESULTS AND ANALYSIS} given as:

Figure 7 describes the methodology for our proposed system. The approach of the methodology is

\subsection{GSM module}

The wireless modem GSM stands for the global mobile communication system. In 1970, Bell Laboratories invented the notion of GSM. The mobile communication system is widely used worldwide. GSM is a free, digital cellular platform that works in the $850 \mathrm{MHz}, 900 \mathrm{MHz}, 1800 \mathrm{MHz}$, and $1900 \mathrm{MHz}$ frequency ranges to deliver mobile voice and data services.

GSM was developed as a digital system using the time division multiple access (TDMA) technology for communication. A GSM decodes and reduces data, and then sends them down to its specific time slot via a channel of two separate sources of client data. The optical system can hold $64 \mathrm{kbps}$ to $120 \mathrm{Mbps}$ of data rates [39]. 


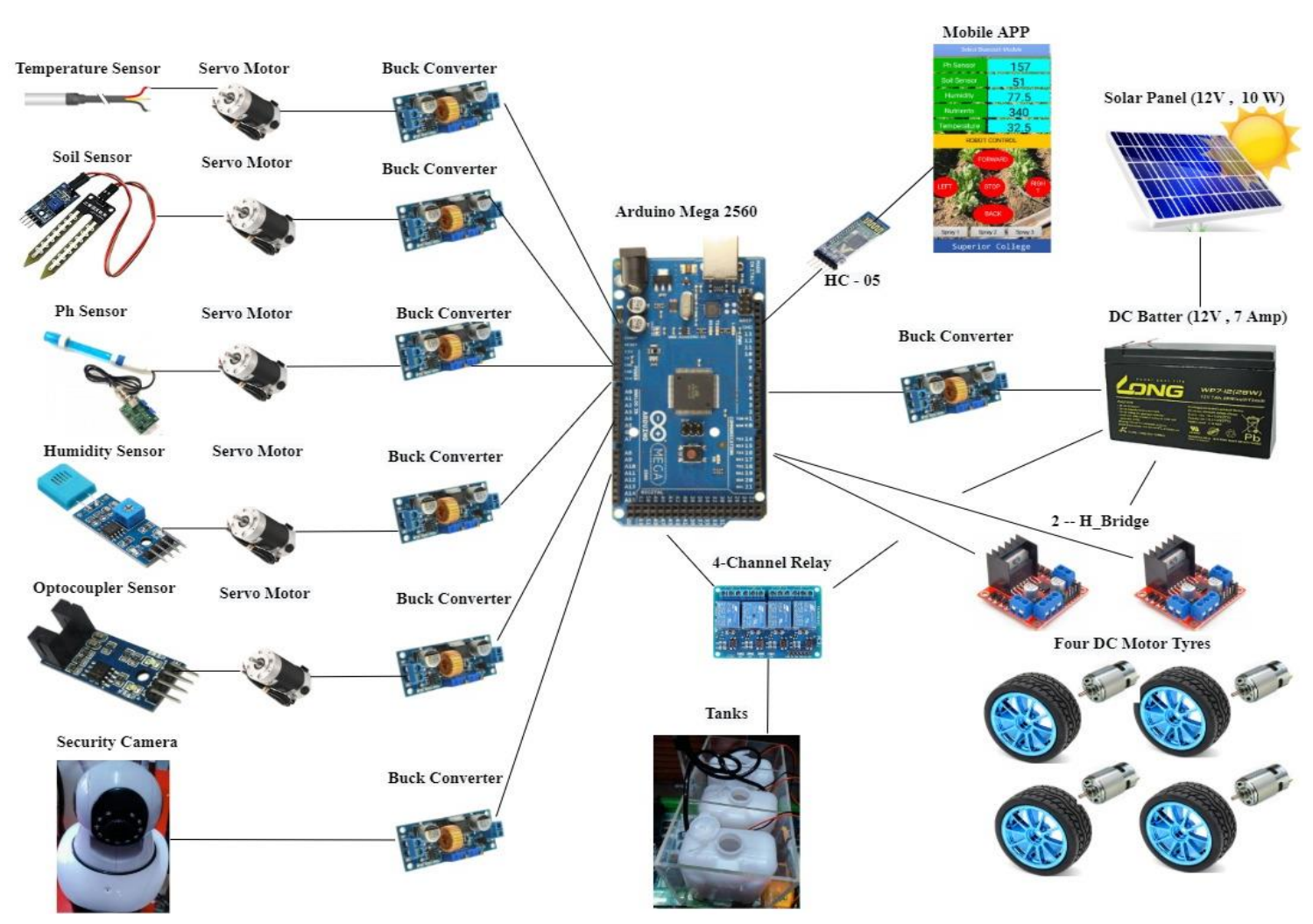

Figure 7. Functional diagram of the proposed system

\subsection{Bluetooth module}

This module can be used to either interface with two microcontrollers like Arduino or connect with any Bluetooth computer such as a phone or laptop. There are already numerous Android applications that make this process much easier [40]. Therefore, it is easy to communicate with any microcontroller assisted by the USART with a 9600 baud-rate.

\subsection{Relay module}

As the relay has a $12 \mathrm{~V}$ voltage source, so the $+12 \mathrm{~V}$ DC supply on one end of the coil and a switch on the other edge of the pitch is used. A transistor, as a switching device, is used here. A diode is attached through the relay belt, which is known as the flyback diode. The diode is designed to protect the switch from high voltage spikes that can be created by the relay coil [41]. As seen, the load end of the typical pin may be connected with the other end of the NO or the NC. If the charge is connected to NO, then it is already disconnected before firing it, and it is connected to NC before triggering it.

\subsection{H-bridge}

The L298 (H-Bridge) is a high-power L293 IC engine unit [42]. It is a powerful, full-bridge dualdriver designed to support normal TTL (control logic) logic levels and drive inductive loads such as relays, solenoids, DC, and stepper. The interface may be activated or disabled separately from the input signals by two active inputs.

\subsection{Opto-coupler}

Opto-isolators prohibit the device from receiving the signal from impacting high voltages. An optoisolator of the typical form consists of the same transparent pack of LED and phototransistor [43]. Optoisolators usually pass digital (ON-OFF) signals, although some techniques allow analog signals to be used.

\subsection{Camera}

The wireless security camera is chosen due to the easy intuitive installation, and the covered area is very clean and $100 \%$ wire free. In addition, the camera has a $130^{\circ}$ view angle large monitoring range as shown in Figure 8. We are using this camera for checking the condition of our crops and for security purposes. A buck-converter is connected to the camera to step down the $12 \mathrm{~V}$ battery voltages to $5 \mathrm{~V}$ because of the operating voltages of the camera are $5 \mathrm{~V}$. The chosen camera has the following specifications in Table 3 . 


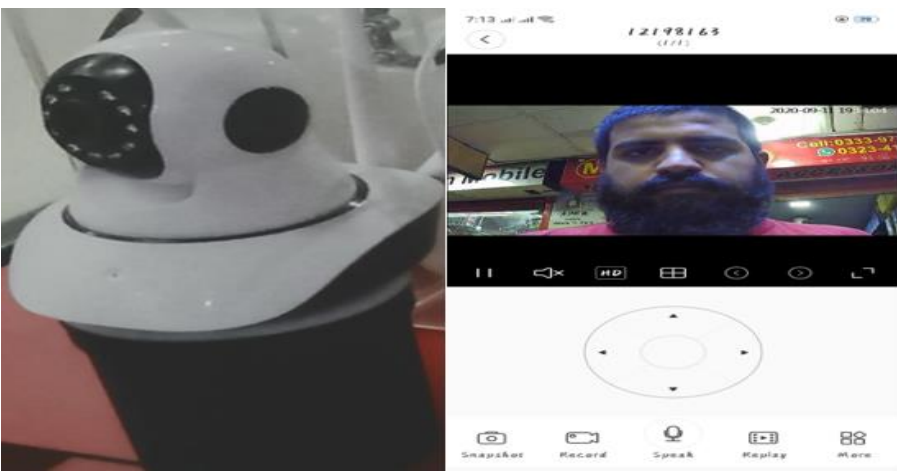

Figure 8. Security camera
Table 3. Specifications of camera

\begin{tabular}{cc}
\hline Specifications & Camera \\
\hline Power supply $(\mathrm{V})$ & $12 \mathrm{~V}$ \\
Technology & Infrared \\
Sensor & CMOS \\
Audio compression & PCM/G.726, Two \\
Connectivity & Way Audio \\
Power consumption & DC 5 V \\
(W) & \\
Communication & Two-Way
\end{tabular}

\subsection{Temperature sensor}

The DS18B20 is a digital temperature sensor with an embedded one wire which is used often in harsh conditions such as pesticides, soil mines, etc. as shown in Figure 9 [44].

Case 1: When we dip the temperature sensor in soil remotely, it gives the temperature of that soil area to a mobile application or PC as provided in Figure 10. The normal temperature is from 30 to $45^{\circ} \mathrm{C}$.

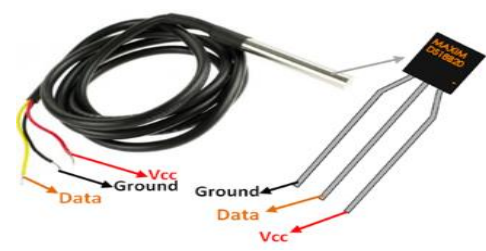

Figure 9. Temperature sensor (DS18B20)

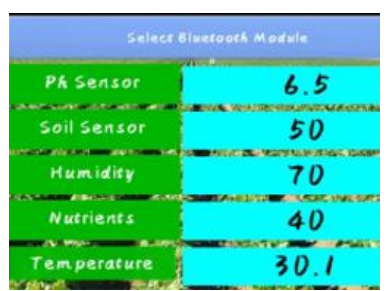

Figure 10. Temperature reading on application

Case 2: When we dip the temperature sensor in warm soil remotely, it gives the temperature of that soil area to a mobile application or PC as shown in Figure 11(a). Now, in this case, temperature exceeds $40^{\circ} \mathrm{C}$, when the temperature of soil exceeds its limit, then we will be notified through SMS that irrigation process is required as mentioned in Figure 11(b). soil, we have:

By substituting values from the Table 4, the amount of heat absorbed is calculated in (1). For dry

$$
\begin{aligned}
& Q=m c \Delta T \\
& Q=0.19 \mathrm{cal} / \mathrm{g}^{\circ} \mathrm{C} \times 100 \mathrm{~g} \times 45^{\circ} \mathrm{C} \\
& Q=855 \mathrm{~J}
\end{aligned}
$$

Change in Temp $=\frac{Q}{m} \times c$

$$
\text { Change in Temp }=\frac{855}{0.19 \mathrm{~J} / \mathrm{g}^{\circ} \mathrm{C} \times 100 \mathrm{~g}}
$$

$$
\text { Change in Temp }=45^{\circ} \mathrm{C}
$$

For wet soil, we have the following:

$$
\begin{aligned}
& Q=0.35 \mathrm{cal} / \mathrm{g}^{\circ} \mathrm{C} \times 100 \mathrm{~g} \times 45^{\circ} \mathrm{C} \\
& Q=854 \mathrm{~J}
\end{aligned}
$$


Change in Temp $=\frac{Q}{m} \times c$

Change in Temp $=\frac{854}{0.35 \mathrm{~J} / \mathrm{g}^{\circ} \mathrm{C} \times 100 \mathrm{~g}}$

Change in Temp $=24.4^{\circ} \mathrm{C}$

where

$\Delta T$ : change in temperature

$Q$ : heat absorption or release amount

$m$ : mass of the body

$c$ : specific heat of the body

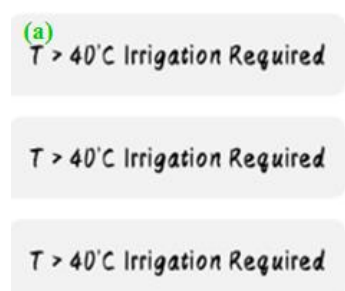

(a)

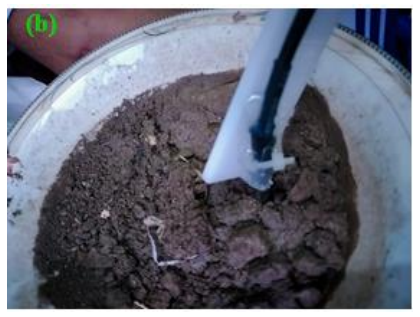

(b)

Table 4. Specific heat [45]

\begin{tabular}{ccc}
\hline Substance & \multicolumn{2}{c}{ Specific Heat $-c_{p}-$} \\
\hline & $\left(\mathrm{cal} / \mathrm{gram}^{\circ} \mathrm{C}\right)$ & $\left(\mathrm{J} / \mathrm{kg}^{\circ} \mathrm{C}\right)$ \\
When soil is dry & 0.19 & 800 \\
When soil is wet & 0.35 & 1480 \\
\hline
\end{tabular}

Figure 11. (a) Notification of temperature and

(b) Temperature sensor case

\subsection{Humidity sensor}

Humidity sensor describes the moisture level of the atmosphere. During rainy or winter seasons when there is an increase in humidity level temperature, it starts decreasing as shown in Figure 12(a). The normal range of humidity is $65-79 \%$. Now, in this case, humidity exceeds $79 \%$, when the humidity exceeds its limit, then we will be notified through SMS that the irrigation process is not required. When humidity exceeds its normal range, we will get notified by SMS through the GSM module to our mobile or PC as revealed in Figure 12(b).

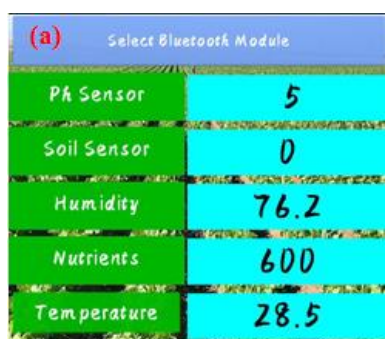

(a)

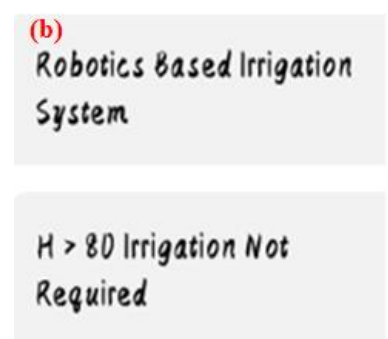

(b)

Figure 12. (a) Humidity level on application and (b) Notification of humidity

For finding relative humidity [46]:

$$
\text { Relative Humidity } \%=\frac{E}{E_{S}} \times 100
$$

where

$E$ : Actual vapor pressure

$E_{S}$ : Saturation vapor pressure 


$$
E=6.11 \times e^{\left(\frac{17.67 \times T_{D e w}}{243.5+T_{D e w}}\right)}
$$

where

$T_{\text {Dew }}=24^{\circ} \mathrm{C}($ at $6 \mathrm{am})$

$$
\begin{aligned}
& E=6.11 \times e^{\left(\frac{17.67 \times 24^{\circ} \mathrm{C}}{243.5+24^{\circ} \mathrm{C}}\right)} \\
& E=29.8
\end{aligned}
$$

Now, we have:

$$
E=6.11 \times e^{\left(\frac{17.67 \times T}{243.5+T}\right)}
$$

where $T: 28^{\circ} \mathrm{C}$.

By substituting values in the above equation, we obtain (17) and (18).

$$
\begin{aligned}
& E=6.11 \times e^{\left(\frac{17.67 \times 28^{\circ} \mathrm{C}}{243.5+28^{\circ} \mathrm{C}}\right)} \\
& E=37.7
\end{aligned}
$$

According to (12), we have:

$$
\text { Relative Humidity } \%=\frac{E}{E_{S}} \times 100
$$

by substituting values of ' $E$ ' and ' $E_{S}$ ' in (14), we get (20) and (21).

$$
\begin{aligned}
& \text { Relative Humidity } \%=\frac{29.8}{37.7} \times 100 \\
& \text { Relative Humidity } \%=79.0 \%
\end{aligned}
$$

\subsubsection{Soil sensor}

The soil sensor displays the level of humidity in the soil. The range for moisture content in soil is $18-23^{\circ} \mathrm{C}$. Initially, it will show $0^{\circ} \mathrm{C}$. We performed this experiment by dipping the sensor in wet soil. Therefore, the sensor reads the moisture level which is up to $50^{\circ} \mathrm{C}$ as shown in Figure 13 (a). After that, we were notified by SMS to mobile or PC that no irrigation is required as mentioned in Figure 13(b).

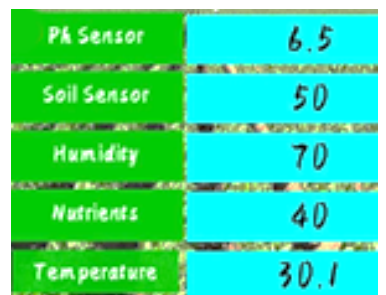

(a)

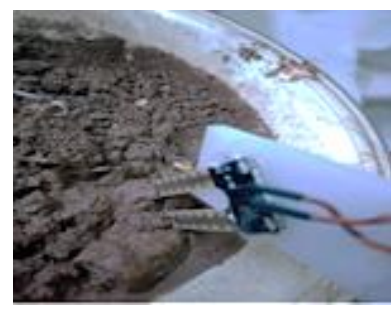

(b)

Figure 13. (a) Soil moisture level on application and (b) Soil sensor case

In (22), the moisture content is calculated in (22) [47]:

$$
\frac{\text { Weight of moist soil }- \text { Weight of dry soil }}{\text { Weight of dry soil }}
$$

Pecentage moisture content (MC) calculations:

Let $M=92 g$ and $D=58 g$ solution: 


$$
\begin{aligned}
\% M C & =\frac{92-58}{58} \\
\% M C & =58.6 \%
\end{aligned}
$$

\subsection{2. pH sensor}

The normal range of $\mathrm{pH}$ is 7.0 (alkaline). Below $\mathrm{pH}$ 7, soil is acidic; and above $\mathrm{pH}$ 7, soil is basic. Case 1: First, we test the $\mathrm{pH}$ level of mineral water as shown in Figure 14(a). The results show that the $\mathrm{pH}$ level of water is alkaline and approximately equals to normal range as mentioned in Figure 14(b).

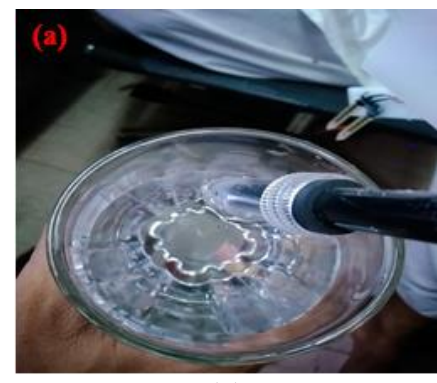

(a)

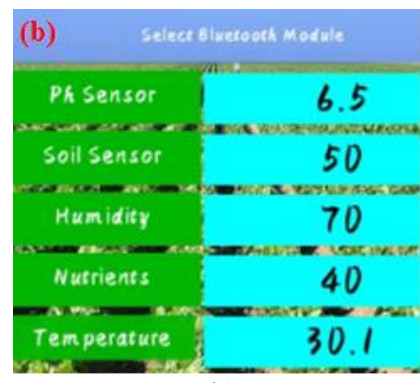

(b)

Figure 14. (a) pH Level and (b) Results of mineral water

Case 2: In this case, we checked the $\mathrm{pH}$ level of contaminated water as shown in Figure 15 (a). Figure 15 (b) shows the result of contaminated water which means it is acidic.

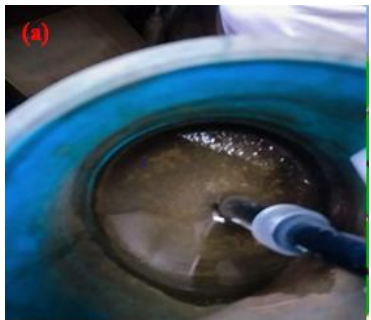

(a)

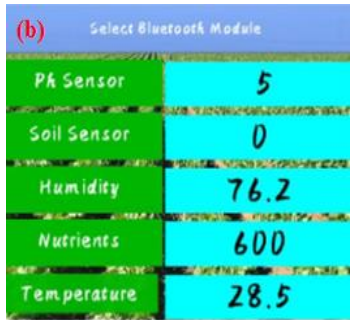

(b)

Figure 15. (a) pH level and (b) Result of contaminated water

\section{Significancy of our System}

The irrigation systems are applied in many of the foreign countries because of the wastage of water. The scope of our proposed system is:

- to irrigate the maximum amount of field as much as we want (remotely),

- to capture the condition of crops through a high pixel camera,

- to add the soil nutrients through the irrigation pipeline,

- to spray the field that kills pesticides/insects,

- robotics-based, and

- $\quad$ to develop an application along with the GSM module.

\subsubsection{Real-time picture}

This phase comprises the complete hardware equipment described with real figures. The general pin configurations of equipment are also described in detail. The purpose of this phase is to make easy for the reader to understand the required work for conducting this research study. Hardware results are also included. The real-time picture of the research study is shown in Figure 16. This figure showed thoroughly the working technique of our irrigation system based on robotics. The Arduino Mega 2560 manages the whole operation by 'C' programming through a Bluetooth connection between a smartphone application and Arduino. This 
relation is often called the serial communication method that involves transmitting one-bit data at a time. We also used Arduino mega since it runs $62.5 \mathrm{~ns}$ and also has a flash storage $256 \mathrm{~kb}$ in a very short time.

A 12 V DC dry battery charged by solar energy is used, and four $12 \mathrm{~V} \mathrm{DC}$ motors are attached to robot tyres in which robot tyres are fed directly from the battery. The speed and movement of robot tyres often referred to as H-bridge (full bridge) are regulated by two L298 drivers. Each sensor has a servo motor, the buck converter is attached to both sensors and a safety camera because the working voltages of the sensor have a voltage of just 5 volts, the buck transformer is down to 5 DC volts on 12 DC volts. The tanks of the robot are controlled with a 4-channel relay system.

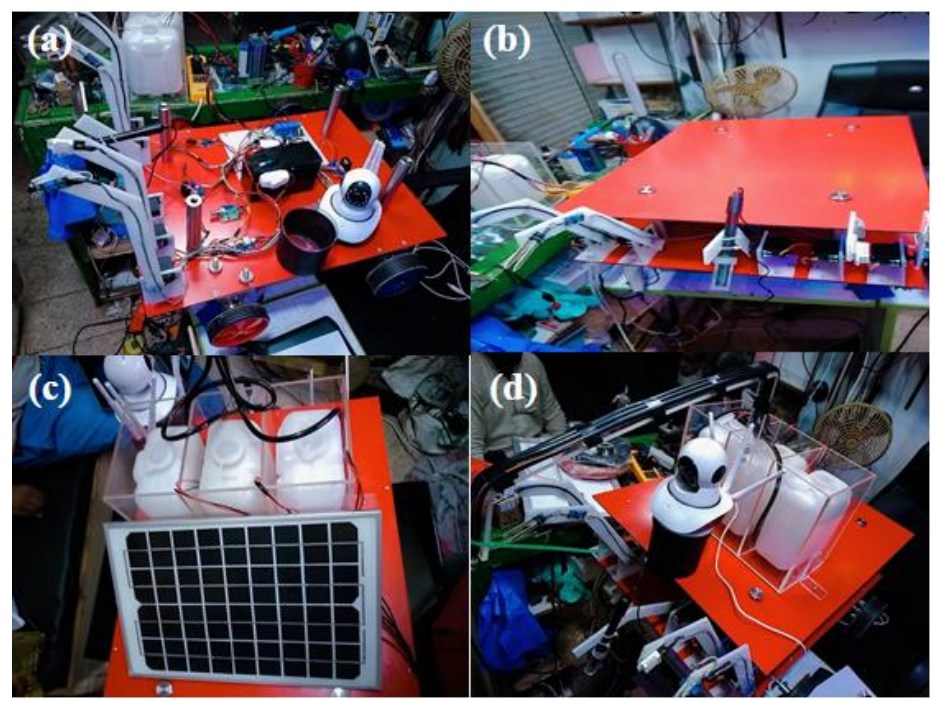

Figure 16. The designed robot process

\section{CONCLUSION}

A comprehensive strategy for the agricultural system was established in this work. The proposed robot-based irrigation mechanism can be deployed to achieve the high yield of crops by the minimum use of water. We have attempted to make this analysis more practical and consistent with the current agricultural market, which takes into account numerous suggestions. Compared to other traditional tracking devices, the Bluetooth-based security system is very useful and effective when sensors are integrated. These sensors detect the ground conditions at various points and then monitor the readings on the mobile application and transmit data to farmers through the GSM module to the mobile phone or PC.

\section{REFERENCES}

[1] S. Vaishali, S. Suraj, G. Vignesh, S. Dhivya and S. Udhayakumar, "Mobile integrated smart irrigation management and monitoring system using IOT," in 2017 International Conference on Communication and Signal Processing (ICCSP), Chennai, India, 2017, pp. 2164-2167, doi: 10.1109/ICCSP.2017.8286792.

[2] G. Vellidis, M. Tucker, C. Perry, C. Kvien, and C. Bednarz, "A real-time wireless smart sensor array for scheduling irrigation," Computer and electronics in agriculture, vol. 61, no. 1, pp. 44-50, 2008.

[3] Q. Kuang, Y. Zhao, and C. Bai, "Automatic monitor and control system of water saving irrigation," Transactions of the CSAE (in Chinese with English abstract), vol. 23, no. 6, pp. 136-139, 2007.

[4] A. U. Rehman, R. M. Asif, R. Tariq, and A. Javed, "Gsm based solar automatic irrigation system using moisture, temperature and humidity sensors," in 2017 International Conference on Engineering Technology and Technopreneurship (ICE2T), Kuala Lumpur, Malaysia, 2017, pp. 1-4, doi: 10.1109/ICE2T.2017.8215945.

[5] S. Taghvaeian, J. L. Chávez, J. Altenhofen, T. Trout, and K. DeJonge, "Remote Sensing for Evaluating Crop Water Stress at Field Scale Using Infrared Thermography: Potential and Limitations," Hydrology Days, pp. 73-83, 2015.

[6] S. Agaian and M. Roopaei, "Method and Systems for Thermal Image/Video Measurements and Processing," US patent 20150244946, Aug 27, 2017.

[7] "Report on the Public Consultation on IoT Governance," European Commission, Jan 16, 2013. [Online]. Available: http://ec.europa.eu/information_society/newsroom/cf/dae/document.cfm?doc_id=1746.

[8] F. Khan, M. A. B. Siddiqui, A. U. Rehman, J. Khan, M. T. S. A. Asad and A. Asad, "IoT Based Power Monitoring System for Smart Grid Applications," in 2020 International Conference on Engineering and Emerging Technologies (ICEET), Lahore, Pakistan, 2020, pp. 1-5, doi: 10.1109/ICEET48479.2020.9048229. 
[9] J. Arshad, et al., "Intelligent greenhouse monitoring and control scheme: An arrangement of Sensors, Raspberry Pi based Embedded System and IoT platform," Indian Journal of Science and Technology, vol. 13, no. 27, pp. 28112822, 2020, doi: 10.17485/IJST/v13i27.311.

[10] A. U. Rehman, M. Tariq Sadiq, N. Shabbir and G. Jafri, "Opportunistic Cognitive MAC (OC-MAC) Protocol for Dynamic Spectrum Access in WLAN Environment," International Journal of Computer Science Issues (IJCSI), vol. 10, no. 6/1, pp. 45-51, 2013.

[11] Y. Yang, H. Cai, Z. Wei, H. Lu, and K.-K. R. Choo, "Towards Lightweight Anonymous Entity Authentication for IoT Applications," Lecture Notes in Computer Science, vol. 9722, pp. 265-280, 2016.

[12] A. Hassan, et al., "A Wirelessly Controlled Robot-based Smart Irrigation System by Exploiting Arduino," Journal of Robotics and Control (JRC), vol. 2, no. 1, pp. 29-34, 2021.

[13] H. Akbari, M. T. Sadiq, and A. U. Rehman, "Classification of normal and depressed EEG signals based on centered correntropy of rhythms in empirical wavelet transform domain," Health Information Science and Systems, vol. 9, no. 1, 2021, doi: 10.1007/s13755-021-00139-7.

[14] S. A. Arif, M. H. Niaz, N. Shabbir, M. H. Zafar, S. R. Hassan, and A. ur Rehman, "RSSI Based Trilatertion for Outdoor Localization in Zigbee based Wireless Sensor Networks (WSNs)," in 2018 10th International Conference on Computational Intelligence and Communication Networks (CICN), Esbjerg, Denmark, 2018, pp. 1-5, doi: 10.1109/CICN.2018.8864943.

[15] S. R. Nandurkar, V. R. Thool and R. C. Thool, "Design and development of precision agriculture system using wireless sensor network," in 2014 First International Conference on Automation, Control, Energy and Systems (ACES), Adisaptagram, India, 2014, pp. 1-6, doi: 10.1109/ACES.2014.6808017.

[16] J. Gutiérrez, J. F. Villa-Medina, A. Nieto-Garibay, and M. Á. Porta-Gándara, "Automated Irrigation System Using a Wireless Sensor Network and GPRS Module," IEEE Transactions on Instrumentation and Measurement, vol. 63, no. 1, pp. 166-176, Jan. 2014, doi: 10.1109/TIM.2013.2276487.

[17] J. Arshad, et al., "A Novel Remote User Authentication Scheme by using Private Blockchain-Based Secure Access Control for Agriculture Monitoring," in 2020 International Conference on Engineering and Emerging Technologies (ICEET), Lahore, Pakistan, 2020, pp. 1-9, doi: 10.1109/ICEET48479.2020.9048218.

[18] V. V. Devi and G. M. Kumari, "Real-Time Automation and Monitoring System for Modernized Agriculture," International Journal of Review and Research in Applied Sciences and Engineering (IJRRASE), vol 3, no.1, pp: 712, 2015.

[19] Y. Kim, R. G. Evans, and W. M. Iversen, "Remote Sensing and Control of an Irrigation System Using a Distributed Wireless Sensor Network," IEEE Transactions on Instrumentation and Measurement, vol. 57, no. 7, pp. 13791387, July 2008, doi: 10.1109/TIM.2008.917198.

[20] Q. Wang, A. Terzis, and A. Szalay, "A novel soil measuring wireless sensor network," in 2010 IEEE Instrumentation \& Measurement Technology Conference Proceedings, Austin, TX, USA, 2010, pp. 412-415, doi: 10.1109/IMTC.2010.5488224.

[21] M. T. Sadiq, et al., "Motor Imagery EEG Signals Classification Based on Mode Amplitude and Frequency Components Using Empirical Wavelet Transform," IEEE Access, vol. 7, pp. 127678-127692, 2019, doi: 10.1109/ACCESS.2019.2939623.

[22] W. Hussain, M. T. Sadiq, S. Siuly, A. U. Rehman, "Epileptic Seizure Detection Using 1 D-Convolutional Long Short-Term Memory Neural Networks," Applied Acoustics, vol. 177, pp. 1-10, June 2021, doi: 10.1016/j.apacoust.2021.107941.

[23] A. U. Rehman, R. Tariq, A. Rehman, and A. Paul, "Collapse of Online Social Networks: Structural Evaluation, Open Challenges, and Proposed Solutions," in 2020 IEEE Globecom Workshops (GC Wkshps, Taipei, Taiwan, 2020, pp. 1-6, doi: 10.1109/GCWkshps50303.2020.9367407.

[24] O. Mirabella and M. Brischetto, "A Hybrid Wired/Wireless Networking Infrastructure for Greenhouse Management," IEEE Transactions on Instrumentation and Measurement, vol. 60, no. 2, pp. 398-407, Feb. 2011, doi: 10.1109/TIM.2010.2084250.

[25] A. Hassan, A. U. Rehman, N. Shabbir, S. R. Hassan, M. T. Sadiq and J. Arshad, "Impact of Inertial Response for the Variable Speed Wind Turbine," in 2019 International Conference on Engineering and Emerging Technologies (ICEET), Lahore, Pakistan, 2019, pp. 1-6, doi: 10.1109/CEET1.2019.8711826.

[26] H. Liu, Z. Meng, and S. Cui, "A Wireless Sensor Network Prototype for Environmental Monitoring in Greenhouses," in 2007 International Conference on Wireless Communications, Networking and Mobile Computing, Shanghai, China, 2007, pp. 2344-2347, doi: 10.1109/WICOM.2007.584.

[27] S. S. Mathurkar, N. R. Patel, R. B. Lanjewar, and R. S. Somkuwar, "Smart sensors based monitoring system for agriculture using field programmable gate array," in 2014 International Conference on Circuits, Power and Computing Technologies [ICCPCT-2014], Nagercoil, India, 2014, pp. 339-344, doi: 10.1109/ICCPCT.2014.7054914.

[28] A. Haider, A. U. Rehman, N. Shabbir, S. R. Hassan, and I. Haider, "A Three Stage Load Sharing Routing Algorithm to Increase Lifetime of Cognitive Radio Sensor Networks," Journal of Communications, pp. 254-260, 2017, doi: $10.12720 / \mathrm{jcm} .12 .5 .254-260$.

[29] R. M. Asif, et al., "Design and analysis of robust fuzzy logic maximum power point tracking based isolated photovoltaic energy system," Engineering Reports, vol. 2, no. 9, 2020, doi: 10.1002/eng2.12234.

[30] M. K. Gayatri, J. Jayasakthi and G. S. Anandha Mala, "Providing Smart Agricultural solutions to farmers for better yielding using IoT," in 2015 IEEE Technological Innovation in ICT for Agriculture and Rural Development (TIAR), Chennai, India, 2015, pp. 40-43, doi: 10.1109/TIAR.2015.7358528. 
[31] A. Abdullah, S. Al Enazi, and I. Damaj, "AgriSys: A smart and ubiquitous controlled-environment agriculture system," in 20163 rd MEC International Conference on Big Data and Smart City (ICBDSC), Muscat, Oman, 2016, pp. 1-6, doi: 10.1109/ICBDSC.2016.7460386.

[32] H. Channe, S. Kothari, and D. Kadam, "Multidisciplinary Model for Smart Agriculture using Internet-of-Things (IoT), Sensors, Cloud-Computing, Mobile Computing \& Big-Data Analysis," Int. J. Computer Technology \& Applications, vol 6, no. 3, pp. 374-382, 2015.

[33] K. Kansara, V. Zaveri, S. Shah, S. Delwadkar, and K. Jani, "Sensor based Automated Irrigation System with IOT: A Technical Review," International Journal of Computer Science and Information Technologies, vol. 6, no. 6, pp. 5331-5333, 2015.

[34] A. U. Rehman, R. A. Naqvi, A. Rehman, A. Paul, M. T. Sadiq, D. Hussain, "A Trustworthy SIoT Aware Mechanism as an Enabler for Citizen Services in Smart Cities," Electronics, vol. 9, no. 6, pp. 918, 2020.

[35] A. G. N. Bandara, et al., "Smart irrigation controlling system for green roofs based on predicted evapotranspiration," in 2016 Electrical Engineering Conference (EECon), Colombo, Sri Lanka, 2016, pp. 31-36, doi: 10.1109/EECon.2016.7830931.

[36] A. U. Rehman, A. Jiang, A. Rehman, A. Paul, S. Din, and M. T. Sadiq, "Identification and role of opinion leaders in information diffusion for online discussion network," Journal of Ambient Intelligence and Humanized Computing, 2020, doi: 10.1007/s12652-019-01623-5.

[37] A. U. Rehman, A. Jiang, A. Rehman, and A. Paul, "Weighted Based Trustworthiness Ranking in Social Internet of Things by using Soft Set Theory," in 2019 IEEE 5th International Conference on Computer and Communications (ICCC), Chengdu, China, 2019, pp. 1644-1648, doi: 10.1109/ICCC47050.2019.9064242.

[38] G. A. Jafri, A. U. Rehman, and M. T. Sadiq, "Spectrum Sensing and Management in Cooperative Cognitive Radio," M.S. thesis, Blekinge Institute of Technology, Sweden, 2011.

[39] D. Rouzaneh, M. Yazdanpanah, and A. B. Jahromi. "Evaluating micro-irrigation system performance through assessment of farmers' satisfaction: implications for adoption, longevity, and water use efficiency," Agricultural Water Management, vol. 246, 106655, 2021.

[40] E. Pazouki, "A practical surface irrigation system design based on volume balance model and multi-objective evolutionary optimization algorithms," Agricultural Water Management, vol. 248, 106755, 2021.

[41] T. Rahman, I. Ullah, A. U. Rehman and R. A. Naqvi, "Notice of Violation of IEEE Publication Principles: Clustering Schemes in MANETs: Performance Evaluation, Open Challenges, and Proposed Solutions," IEEE Access, vol. 8, pp. 25135-25158, 2020, doi: 10.1109/ACCESS.2020.2970481.

[42] T. Muhammad, B. Zhou, Z. Liu, X. Chen, and Y. Li, "Effects of phosphorus-fertigation on emitter clogging in drip irrigation system with saline water," Agricultural Water Management, vol. 243, p. 106392, 2021.

[43] A. Mungsunti and K. A. Parton. "The Price of Sustainability of a Traditional Irrigation System in Northern Thailand," Sustainability, vol. 13, no. 3, 1375, 2021.

[44] J. Cao, et al., "Mapping paddy rice using Landsat time series data in the Ganfu Plain irrigation system, Southern China, from 1988-2017," International Journal of Remote Sensing, vol. 42, no. 4, 1556-1576, 2021.

[45] A. Brandyk, E. Kaca, R. Oleszczuk, J. Urbański, and J. Jadczyszyn. "Conceptual Model of Drainage-Sub Irrigation System Functioning-First Results from a Case Study of a Lowland Valley Area in Central Poland,” Sustainability, vol. 13, no. 1, pp. 107, 2021.

[46] V. H. B. Nogueira, et al., "Variation in the flow rate of drip emitters in a subsurface irrigation system for different soil types," Agricultural Water Management, vol. 243, 2021.

[47] R. Pinto, C. Mathias, N. Kokande, M. Thomas. and U. S. Pushpas, "Solar Powered Irrigation System," Nanoelectronics, Circuits and Communication Systems, pp. 369-381, 2021.

\section{BIOGRAPHIES OF AUTHORS}
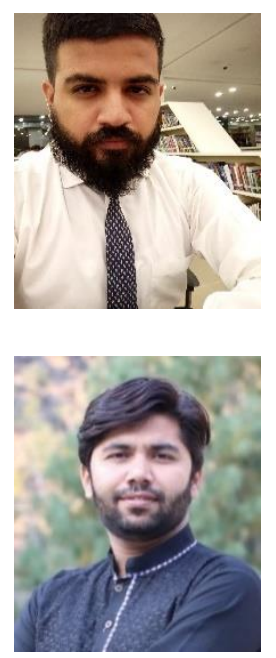

Ahmed Hassan received a Bachelor's degree in electrical engineering from The Superior College, University Campus, Lahore, Pakistan, in 2020. After completing his BS Degree, He remained with the same college in the capacity of a Lab Engineer. His research interest includes Industrial Automation, Smart Grid, Photovoltaic System, and Digital Control System.

Rao Muhammad Asif was born in Multan, Pakistan, in 1991. He received his BS Degree in electrical engineering from The Superior College, Lahore, Pakistan, in 2013 and MS degree in electrical engineering with a specialization in power from The Superior College, Lahore, in 2015. After completing his BS degree, he remained with the same college in the capacity of a Lab Engineer. Since 2016, he is working as a Lecturer in The Superior College, Lahore, Pakistan. Currently, he is pursuing a pH.D. degree in the same institute. His research interests include smart grid, solid state devices, and renewable energy resources. 

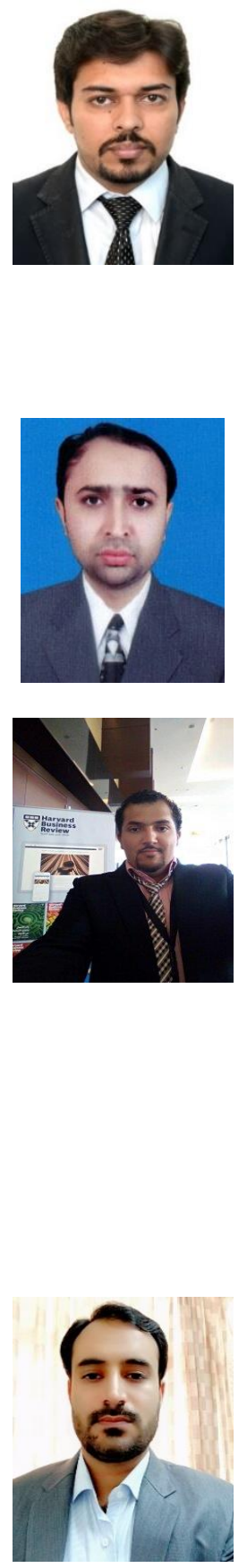

Ateeq Ur Rehman was born in Rawalpindi, Pakistan, in 1987. He received his BS degree in electrical (telecommunication) engineering from COMSATS Institute of Information Technology (CIIT), Lahore, Pakistan, in 2009 and MS degree in electrical engineering with a specialization in telecommunications from Blekinge Institute of Technology (BTH), Karlskrona, Sweden in 2011. From 2011 to 2012, he was a lecturer with the Department of Electrical Engineering, University of South Asia, Lahore, Pakistan. From 2012-2016, He joined the Faculty of Engineering and Technology, The Superior College (University Campus) Lahore, Pakistan in the capacity of a Lecturer. Since 2016, He is working as a Lecturer in Government College University (GCU), Lahore, Pakistan (on study leave). Currently, He is pursuing a pH.D. degree in the College of Internet of Things (IoT) Engineering, Hohai University (HHU), Changzhou Campus, China. His research interests include biomedical signal processing, Internet of Things (IoTs), Social Internet of Things (SIoTs), and big data.

Zuhaib Nishtar received BSc degree in electrical engineering and MS electrical engineering in 2013 in 2017 respectively from The Superior College Lahore, Pakistan. He worked as a research associate in the Electrical Engineering Department of Riphah International University Lahore. He is currently pursuing his pH.D. in electrical engineering from The Superior College Lahore, Pakistan. His current research interest includes smart grid technology, power electronics, renewable energy resources, and wireless sensor networks

Mohammed K. A. Kaabar received all his undergraduate and graduate degrees in mathematics from Washington State University, Pullman, WA, USA. He has a global diverse experience in teaching and research. He is currently working in the field of fractional differential equations, applied math, fractal calculus, and applied analysis with applications to science and engineering. $\mathrm{He}$ is the national ambassador for Palestine at various non-profit organizations in Italy and Argentina, sponsored by the University of Milan-Bicocca and United Nations Global Compact, respectively. He worked as an adjunct math professor at Moreno Valley College, USA. He authored two math textbooks, and he is an invited referee for many international scientific and engineering conferences and journals. He is also an invited reviewer for Zentralblatt MATH (zbMATH) in Berlin, Germany. He is also serving as an associate editor for the Bulletin of Electrical Engineering and Informatics, IAES International Journal of Artificial Intelligence, Journal of Education and Learning (EduLearn), TELKOMNIKA, and IAES International Journal of Robotics and Automation. He is also an editor for the Journal of Multidisciplinary Applied Natural Science, sponsored by the Physical Society of Indonesia. He is an associate editor for the mathematics section of the non-profit educational program at California State University, Long Beach, CA, USA. He is also a member of the expert editorial advisory board for the big data and advanced wireless technologies springer book series.

Khan Afsar received his B.S. in electrical (telecommunication) engineering (Feb. 2004-Mar. 2008) from COMSATS Institute of Information Technology, Lahore (Pakistan) and M.S. in Electrical (Telecommunication) Engineering (Aug. 2009-Jun. 2012) from the same institute. Currently, He is working as a lecturer in the Electrical and Computer Engineering Department, COMSATS University Islamabad, Pakistan. 